\title{
Irony in Kate Chopin's Selected Short Stories
}

\author{
Hazha Salih Hassan ${ }^{1}$ Chinar Kamal Tayib ${ }^{2}$ \\ ${ }^{1}$ Department of English Language, College of Basic Education, Salahaddin University- Erbil, Kurdistan Region, Iraq \\ 2 Department of English Language, College of Basic Education, Salahaddin University- Erbil, Kurdistan Region, Iraq
}

\begin{abstract}
Whereas there has been ample Many authors often employ irony as a powerful literary device since it makes the language of their literary works more suggestive and more emphatic. They usually use irony as a kind of satire, thereby to emphasize faults in their characters or in society in general. Among the American writers who use irony in their short stories is Kate Chopin. This study aims to discuss the nature of irony in Kate Chopin's three short stories, "The Story of an Hour", "The Storm", and "Desiree's Baby". The study tries to analyze the presence of three main types of irony, their functions, their relation to the theme or message of the story, and the reasons behind the use of irony. The study concludes that though Chopin satirizes her contemporary society through irony, her irony is neither humorous nor funny but invariably tragic. She deliberately uses irony in her stories. She creates an atmosphere of suspense by adding turns and twists to the stories in order to shock the reader. Another reason for using irony is to employ her unconventional ideas about the condition of women and to bring the reader to the main theme of the story. Moreover, the ultimate goal behind all is to criticize as well as to highlight the flaws of the American patriarchal society of her lifetime and to support her feminist ideas.
\end{abstract}

KEY WORDS: Desiree's Baby, Irony, Kate Chopin, The Storm, The Story of an Hour.

\section{INTRODUCTION}

One aspect of writing style is the use of irony. Writers use irony to contribute much to the development of their indirect literary style, as a powerful literary device to bring the reader to the main themes of their stories. Irony is a rhetorical means in which there is always a sharp contrast or incongruity between what is said or expected to happen and what is really meant or what really happened. All the types of irony can be noted in a literary work. "Verbal irony is a statement in which the meaning that a speaker implies differs sharply from the meaning that is ostensibly expressed" (Abrahams and

Koya University Journal of Humanities and Social Sciences (KUJHSS).

Volume 3, Issue 1, 2020.

Received 16 August 2019; Accepted 16 January 2020, Regular research paper: Published 26 June 2020

Corresponding author's e-mail: hazha.hassan@su.edu.krd Copyright (C2020 Hazha S. Hassan \& Chinar K. Tayib. This is an open access article distributed under the Creative Commons Attribution License.
Harpham, 2009, p.165). Li (2008, p.5) considers situational irony as "an incongruity in a situation arising from tension between what is expected or intended and what actually happens". Abrahams and Harpham (2009, p.167) view dramatic irony as one that involves a situation in a play or narrative in which the audience or reader shares with the author knowledge of present or future circumstances of which a character is ignorant. In that situation, the character unknowingly acts in a way we recognize to be grossly inappropriate to the actual circumstances, or expects the opposite of what we know that fate holds in store, or says something that anticipates the actual outcome, but not at all in the way that the character intends.

It is worth noting that irony in literature is used for a variety of purposes. It is used to emphasize a certain theme. It is an effective and strong literary device implemented by many writers for decoration to create a twist of fate and to give many turns in a way that the final events revert back on the prior ones, or else to create suspense. It is utilized for its social function in order to convey the viewpoint of the speaker toward a certain social problem. It is used to bring the readers 
some real social issues covered with deep and unexpected irony either in a form of utterances said by some characters, an unexpected situation, or misunderstanding and unawareness among characters. It is employed to evaluate, criticize, scorn, and state the truth indirectly. It is also adopted to show some degree of emotional control which makes the reader take into account, which expectations he/she has, or what the speaker intends. Additionally, irony is a means used to play around with words in a way that the meaning suggested by them is actually opposite to their literal meaning.

\section{FACTORS INFLUENCED KATE CHOPIN'S WRITINGS}

Chopin is a late nineteenth-century American fiction writer who was born in St. Louis, Missouri in 1851. "She was the daughter of an Irish immigrant father and a St. Louis mother" (Boriçi: 2013, p.314). Her works deeply reflect the antebellum (before the civil war) southern Creole society. She used her writing to express her disappointments toward the contemporary concepts of her age. She was greatly influenced by her struggle with her own life and society. Her beliefs and personal experiences are clearly revealed in her stories. "Her writing efforts make up for her losses and sorrows in her early life and help develop empathy and understanding for others' pain particularly the displaced in the Southern society such as working-class Creoles and black women" (Sulha:2014, p.274). Many factors assisted to shape her perspectives about life, society, and her unconventional ideas. These all in turn are deeply mirrored in her writings.

The most influential factor reflected in Chopin's writings is the social condition of women. At her time, women were oppressed and dominated by men. They hardly had any rights and they were not regarded as equivalent to men. In spite of attempts by women'srights supporters, by the end of the century women still had not had the right to vote in elections. Victorian Society expected women to be conventional. She thinks that women are trapped in unhappy marriages. They are supposed to be up to standard, devoted, submissive, self-sacrificing, powerless, and meek. They were required to keep house, cook, bear and rear children only. Factory owners and businessmen discriminated against women by employing them for low grade work and less wages than men. Another factor on her having an unconventional life is first, "Kate Chopin was educated in a Roman Catholic convent school where she was exposed not only to catholic teachings but also to a French emphasis on intellectual vigor"(Boriçi: 2013, p.314). Second, her father died while she was five and she was raised in an unconventional matriarchal family without having been dominated by any man. She lived with her mother, grandmother, and great grandmother who were all widows. "After her father's death in 1855, Kate's great-grandmother, Mme. Charleville, became the person who influenced her the most. Conversing with her in French, this wise old lady taught her to face life without embarrassment or self-consciousness, and not to judge people on appearances" (Boriçi: 2014, p.310). Therefore, this affected her independence which in turn was profoundly reflected on her writings. Third, most of the members of her family such as her father, grandmother, and half-brother died on religious days, occasions, and celebrations. All these sad incidents made her strongly doubtful towards religion. Consequently they greatly affected her stories. Furthermore, her husband was another significant figure who helped to shape the patterns of her writings. She married him at the age of twenty, who was like Kate from a French catholic family. He loved her so much as well as "admired her independence and intelligence, and allowed her unheard of freedom" (Wyatt: 1995, p.2). But unfortunately she was widowed at the age of 32, an incident that added to her agonies. She was left alone with six children in great destitution and burdened with running her late husband's store and plantation. Consequently, as a very mature woman, in 1887, she started writing fiction: at first, as rehabilitation from the depression that she suffered after the death of both her husband and her mother, and later as a support to herself and her family. She published many short stories, poems, essays, and sketches in literary magazines.

Although Chopin never viewed herself as a feminist, some critics consider her to be a predecessor of the feminist authors of the 20th century (Boriçi: 2014, p.248). She became the forerunner of feminism in the world's literature because of her unique style. In her works, she portrays women in a less conventional way than her contemporaries. She concentrates upon the nineteenthcentury women's rights, personal wants, and needs. Themes of her stories include women's independence and sense of self-assertion, quest for identity, issues of gender, race, and class discrimination. Her works were strongly criticized and rejected by many critics of her period. She is also described as "a woman before her time" (Tas, 2011: p.413) or "a woman much ahead of her time" (Hicks, 2009: p.35).

\section{IRONY IN CHOPIN'S “THE STORY OF AN HOUR"}

"The Story of an Hour" is a short story about a young married woman, Louise Mallard, of the late nineteenth century as she responds to the news that her husband has died in a train accident. The story was published in 1894. It is filled with irony. One can say it is Chopin's masterpiece of irony: it starts and ends with irony. All three varieties of irony are used by Chopin in this story 
as a powerful literary device to provide the story with several twists and sharp turns to achieve particular effect. In "The Story of an Hour" Chopin deals ironically with the problems of female freedom, self-discovery, and identity". She foregrounds her heroine as a woman who decides to exercise her independence as a human being. She is concerned with the needs and wants of women of her time in an indirect way. "The Story of an Hour" is the dream of female liberty that lasts only for one hour. Verbal irony is used right from the beginning when Mrs. Mallard's spiritual disease is called heart troub, "knowing that Mrs. Mallard was afflicted with a heart trouble ... ." (Chopin, 1969: p.352). Ironically, her disease is not physical as the reader may first suppose or understand; rather it is psychological or spiritual, the ache of a repressed spirit inside her. Because of her illness, Mrs. Mallard's sister (Josephine) and Brently Mallard's friend (Richards) are careful in breaking to hear the news of her husband's death. They think that the news would destroy her as she would not bear the sad news due to her weak heart. They are not aware of the fact that the news will bring her great joy and extreme happiness. The irony being presented here reflects the discrepancy between the characters' understanding of her condition and her real condition. Here, it is worth noting that Chopin used situational irony to create suspense or tension and make readers wonder and eager to know what will happen to Mrs. Mallard after knowing about her husband's death. This makes the readers worry about her as they are merely informed that she is ill. In fact, the opposite of all the above happens.

Another ironic point in the story is that when Chopin refers to the way in which Louise as a widow feels before her reaction is revealed, "she did not hear the story as many women have heard" (ibid). She expresses her grief in an overwhelming manner by weeping at once as it is expected from here to feel bad about her husband's death. Yet her "sudden wild abandonment, in her sister's arms" (ibid) is situational irony. It refers to her relief at being abandoned or having her freedom by Brently's death. Unlike other women, she accepts the news and goes to her room wishing to be alone. The situation is ironic because that is not expected from her. The readers expect a woman (especially a traditional Victorian woman) who just hears of her husband's death to be full of mourning. Here, the opposite occurs, and Mrs. Mallard is shown to actually take joy in the news of her husband's death. Her reaction to the death of her husband is ironic. In this scene, irony is used to emphasize a certain universal truth which is the woman"s identity. Through the use of irony, Chopin wants to say that Mrs. Mallard's reaction toward her husband's death is also accepted. When she ascends up to her room, it is asserted that she was "pressed down by a physical exhaustion that haunted her body and seemed to reach into her soul" (p.353) is ironic because it is not sadness, but suppression in a male- dominated society that tires out Mrs. Mallard.

As the sob comes "into her throat and shook her, as a child who has cried itself to sleep continues to sob in its dreams" (ibid), Mrs. Mallard is weeping so as to release her emotion from being repressed and suppressed by her husband and the society, rather than grieving for her husband. Ironically, instead of expecting her death, she is overwhelmed with the expectation of getting her own life back. When Mrs. Mallard encounters nervously the "thing that was approaching to possess her" (ibid), sitting in her chair looking out the window, she "strives to beat it back with her will" (ibid) as if she does not like to accept it. But, in fact, her fear is that it is unbelievable, not that it is fearful in itself. For, as she says the words "free, free, free!" the "look of terror that had followed it" (ibid) goes from her eyes. Ironically, her heart beats fast and her flowing blood "warmed and relaxed every inch of her body," (ibid) for the moment of being free.

Mrs. Mallard is secretly happy when alone in her room, locking the door behind herself, having a startling moment of "self-assertion", feels free "Free! Body and soul free" (ibid) because she is now free. She is filled with a new lust for life, and although she usually loved her husband, she cherishes her newfound independence even more. She has "a brief moment of illumination"(ibid) as she reflects on the fact that she can live independently: "There would be no powerful will bending hers in that blind persistence with which men and women believe they have a right to impose a private will upon a fellow-creature" (ibid). Ironically, the return of Bentley Mallard "imposes" upon her to the degree that she dies. As Mrs. Mallard locks her room behind herself, her sister, Josephine, is worried, fearing that she will harm herself. She begs her to open the door; she does not know that this moment is the happiest moment in her life. There is dramatic irony in this scene as her sister is unaware, while the readers are aware, of what goes on in Louise's mind. In this scene, even the description of the weather is ironic. Usually, when there is sad news the weather is described as gloomy and dark, this is to reflect the character's sadness: Here in this story, there is not any reference to unpleasant weather, on the contrary, the time is spring, the weather is very nice, everything is fine, birds are singing, trees are fresh. To ironically compare how life goes inside and outside Mrs. Mallard's home there is a great contrast and huge discrepancy between the dreariness and solitude of her room and the cheerful spring day outside. While she is trapped with the chains of marriage there is a joyful and cheerful life outside the territory of her home since there is liberty there. Again, irony here is used to create suspense or tension in the 
story. At the time the readers are aware of Mrs. Mallard's new ideas other characters do not know anything, they think that Louise might harm herself; for the readers this adds the suspense and tension. Another irony is that while Mrs. Mallard is in her room, she drinks in the "very elixir of life through the open window"; she wishes that life "might be long". Yet, as she steps toward the downstairs, death embraces her. Likewise, while descending the stair, Louise Mallard "carries herself unwittingly like a goddess of Victory" (ibid); however, she is defeated by the return of her husband.

Another dramatic irony in the story is that as Brently Mallard returns home suddenly, Richard does his best to hide his friend so as not to be seen by his wife. He thinks that the sudden joy would have an effect on her weak heart. He does not know that she will be shocked by her husband's return and this will bring her extreme sadness as opposed to joy. Once more, the irony is used to prompt suspense in the story. The last scene is also ironic. There is a verbal irony when the doctors say "she died of joy that kills" (354), here there is an oxymoron; two things that are incompatible, joy cannot kill at all, in fact the reverse is true i.e. sadness can kill. Also, the whole situation is a dramatic irony as Josephine, Richards, the doctors, and all people believe that Louise becomes so thrilled when she knows that her husband is alive and home again and she is so overwhelmed with joy at seeing her beloved husband still alive that the shock kills her. So, they think that she dies of happiness, while in fact; the readers know that her shock is for massive disappointment and sadness. Her newfound dreams of freedom and autonomy are now dashed to the ground as she realizes that she is still stuck in an oppressive marriage by her husband's reappearance. Her death is not of joy but of extreme sadness. This verbal irony is to create a sarcastic tone as all the other characters, including her husband, do not understand Louise: they believed that she died of joy. Another situational irony can also be observed here as $\mathrm{Mr}$. Mallard actually being alive at the end whereas Mrs. Mallard is dead. The last irony is that Mrs. Mallard does not die because of the bad news but because of hearing the good news. This last situational irony is created to heighten the readers' emotional response when Louise meets her death and the story ends tragically. The irony leads the readers to feel pity for Louise and put the blame on the society that is dominated by men since they regard her as victim of nineteenth-century marriage.

In short, one can conclude that the whole story is ironic as there is a gap or incongruity between what is said, acted, or taken as a reaction and what is meant, understood, or expected in order to create a twist of fate: instead of Mr. Mallard's death, Mrs. Mallard meets her death. Chopin's use of irony makes a seemingly very simple short story a more profound one, thereby creating a deeper meaning than is immediately apparent.

\section{IRONY IN CHOPIN'S “THE STORM"}

"The Storm" is one of the most daring stories in American literature of the time. Chopin did not even try to publish it during her lifetime. It was published after Chopin's death. Here the main character, Calixta, commits adultery during a storm, but instead of feeling guilty over an act considered a sin in her time, she feels liberated. At a time when women were expected to behave properly, that is to have limited sexual desire and to act passively, Calixta goes against her society's standard of virtue. She chooses to give in to her emotions. Like the real storm of the story, Calixta becomes a force of nature who seeks fulfillment outside her home. (Boriçi, 2014: p.249)

Chopin's "The Storm" is also full of irony. Like "The Story of an Hour", Irony dominates "The Storm" from start to finish. All types of irony can be noted in this story. The story contains verbal, situational, and dramatic irony. The story is highly ironic to deal with a highly controversial theme which was taboo in her time. Through the use of irony she defies conventions; the story implies that the sin of infidelity can be a good thing.

The setting of the story, which is at the same time the title of the story, "The Storm", and the heavy rain, are ironic because as Chopin constructs the plot of the story she continuously refers to the fact that the storm is very ruinous and frightening, but later it is discovered that the fear is over when desire and passion take its place. Moreover, readers discover that the storm does not destroy the relationship of the characters with their spouses: instead, the storm ironically intensifies their belonging as it is stated in the end when Calixta's son Bibi and her husband Bobinot are home again. Alcee writes a love letter to his wife and the story ends with this sentence: "So the storm passed and everyone was happy" (Chopin, 1969:569). There is further irony in the setting of the story, i.e., in the storm and the heavy rain: Alcee and Calixta can escape the rain by working together to protect the house from the water that the rain brings. Meanwhile, ironically, the real storm which represents their erotic desire cannot be avoided.

When the storm starts Calixta's husband Bobinot and her four-year-old son Bibi are not home. Bibi thinks that his mother will be fearful of the storm since she is home alone. In contrast however, she uses the tempest as an opportunity to cheat on her husband. Bibi's worries about his mother seem to be somehow ironic. Moreover, Bobinôt's speech to his son telling him that his mother will close the doors and the windows of the house 
tightly due to the storm is irony again. On the contrary, she opens her bedroom for a foreigner. Furthermore, both Calixta's husband and her son's great concerns for her safety are ironic. There is a situational irony from the point where the writer describes Calixta's being busy with her housework as she is sitting at her sewing machine without noticing the gathering of the storm. However, when she eventually notices the approaching storm Chopin still portrays her as a devoted housewife who cares about her home: she hurries out to bring in the laundry that is hanging to dry; she shuts the windows and the doors. Ironically, she meets society's expectations of a wife who is caring, busy with her house duties, the one who worries about her son and husband because they are out. But that worry is replaced by passion as she meets Alcee her previous lover: this situation leads her to forget about her family and surrender to her physical impulse. This affair makes the whole situation ironic: there is a sudden turnabout from a committed wife to a person who possesses an erotic desire. On the other hand, if we look at the scene from another angle we can note that the situation is also ironic because, when they knew each other before, while they were both free, Alcee did not expect that he could violate her honor. "If she was not an immaculate dove in those days, she was still inviolate; a passionate creature whose very defenselessness had made her defense, against which his honor forbade him to prevail" (ibid: p.594). Furthermore, Alcee thinks that "Calixta now knows "her birthright" for the first time: ironically, "Her firm, elastic flesh that was knowing for the first time its birthright.... (ibid)".

There is another situational irony in the story, which is in the way their union is presented: Expressions such as "Calixta knowing her "birthright" while having an extramarital affair with Alcee" indicates that she will be unable to go back to her husband after this. However, after the storm of passion that has been released, both Calixta and Alcee are seen to return even happier than before to their spouses. The irony is that Chopin shockingly and daringly implies that such outlets of stormy passion can actually enhance marriage rather than destroy it. Readers expect that their stormy moment of the erotic union would harm their respective marriage: rather, the affair benefits them as they returned to their family happier than before. In addition, there is also a dramatic irony in the last scene of the story, after the end of the storm, Calixta is very happy to see her son and her husband. Similarly, Alcee writes his wife an amorous letter. Here, the readers are aware of their erotic union, but none of their partners suspect their unfaithfulness. Bobinôt's act of buying a can of shrimp for Calixta is also ironic. The act shows Bobinot's care for his wife (Calixta) who has just committed adultery and is unfaithful to him. Another situation that indicates his concern for his wife, which is also ironic, is his concern that he with his son Bibi are far too stained with mud to merit Calixta's meeting them on their way back home after the tempest. "My! Bibi, w'at will yo' mama say! You ought to be ashame'. You oughta' put on those good pants. Look at 'em! An' that mud on yo' collar! How you got that mud on yo' collar, Bibi? I never saw such a boy!" Bobinot says (ibid, p.595). Moreover, another dramatic irony in the story is when Alcee writes to his wife, telling her that it would be alright for she and their children to stay a while longer in Biloxi, indeed, they might stay for another month, and she accepts the suggestion with pleasure, regards the chance as "her first free breath since her marriage," that "seemed to restore the pleasant liberty of her maiden days"(ibid, p.596) The irony here is that Clarisse, in being away from her husband, is enjoying a kind of independence she has not felt since they were married, as much as Alcée has enjoyed the freedom of being away from her.

The story is not free from verbal irony: some words have double meaning such as the word "Assumption". When Alcee asks Calixta whether she "remembers in Assumption"( ibid, p.594), this alludes to their previous erotic connection, where once they surrendered to their physical desires so as to enjoy themselves in the city of "Assumption". Assumption as a city name refers to Alcee's "assumption" or presupposition that Calixta who has a husband and a child now - will not agree to have an affair with him again. Chopin uses this word on purpose since the word is highly suggestive and it could be interpreted in two different ways as it is mentioned above. The irony is that she accepts his request and submits to her desire. The quote "Enough sense to come in out of a cyclone", by Alcee, is verbal irony. When Calixta is anxious about the security of her husband and her four-year- old child during the storm as they are out, Alcee answers: "Let us hope, Calixta, that Bobinôt's got sense enough to come in out of a cyclone" (ibid, p.593) The quote is ironic since, on one hand, it diminishes Calixta's anxiety, but on the other hand, Alcee assumes that it is his right to come in out of the cyclone (the storm) which later, itself, leads to the affair. Most of the phrases that the writer uses to describe her characters and the things around them are verbal ironies: for example, when Chopin describes Calixta as an "overscrupulous housewife" (ibid, p.595), the one who has just behaved in an unscrupulous or immoral manner, after the return of her husband and her son, is verbal irony. Chopins' description of Calixta's bed as "white"(ibid, p.592) in color is ironic as well, because white is a symbol of purity and innocence, especially in view of the fact that the bed itself is used for committing adultery. The author mentions that Bibi's bed is exactly beside the bed in which Calixta has the affair. 
To conclude, the story is highly ironic from the beginning to the last sentence. Every single sentence in the story is ironic. The story is full of twists, sudden and unexpected turns in such a way that the final events turn back on the previous ones. With the help of irony, Chopin hides the illegal behavior of the heroine behind the fear of the storm. Shockingly, she emphasizes the importance of women's independence. Overall, irony is employed to suggest the taboo meaning which Chopin wishes to advance.

\section{IRONY IN CHOPIN'S “DESIREE'S BABY"}

Another story in which Chopin employs irony is the tragedy "Desiree's Baby". The work was published in 1893. In this story Desiree, as a baby, is found near a Louisiana plantation and adopted by Valmondes. She marries Armand Aubigny who has fallen in love with her. They soon have a baby. Her husband avoids her when it is noticed that the baby has a mixed race. Armand accuses Desiree of being half black. She takes her baby and leaves the house. She decides not to take the right road to Valmonde but instead vanishes into the bayou out of despair and disappointment. Eventually, Armand finds a letter written by her mother and realizes that he himself is partly black! The story is another masterpiece of irony. Through the use of irony she deals with the 'problem of miscegenation'. She uses irony to criticize American racial, gender, and class discrimination of antebellum southern society. She emphasizes the point that all types of discrimination destroy individuals and their family lives. Chopin uses the tragedy as a metaphor to show the ironic fact that one is mistaken if he judges the human situations as black and white (Peel, 1990; Wolff-Griffin, 1978). The Story depicts "the verbal and emotional abuse toward women of which domineering and unloving men are capable" (Wyatt-Brown, 2002: p.203). Most of the ironies used in this story are situational as the story is full of turns and twists. The title is ironic as it suggests that the baby is Desiree's not Armand's. Armand believes that the baby's 'mixed race' comes from Desiree not from him. However, as the readers know at the end of the story Armand is responsible for the 'mixed race' not his wife.

One of the ironies of the story is when Madame Valmonde regards Desiree as a child that "had been sent to her by a beneficent Providence to be the child of her affection, seeing that she was without child of flesh"(Chopin, 1969: 240). This is ironic because here Desiree is described as a child sent from God while eventually she and her baby would turn to be a symbol of sacrifice: Desiree sacrifices herself as well as her baby to avoid being a source of shame for her husband. Another irony in the story is that when the narrator describes how Armand Aubigny has fallen in love with
Desiree when once he is riding by and seeing her. The narrator comments "That was the way all the Aubignys fell in love, as if struck by a pistol shot"(ibid). The irony of this scene is in the way all the Aubigny men's love. All the Aubigny men have a blind love experience, the type of love that lead to the death of their wives. It is this type of love that leads to the death of Desiree. The same thing is true for the death of Armand's mother because of his father's love. One more important irony in the story is that when Armand asks Desiree's hand for marriage and Monsieur Valmonde reminds him of "the girl's obscure origin". The narrator states that "Armand looked into her eyes and did not care. He was reminded that she was nameless". He adds "What did it matter about a name when he could give her one of the oldest and proudest in Louisiana" (ibid). The whole situation is ironic especially the last line. It is ironic because Monsieur Valmonde, very frankly, asserts that he does not have any idea about Desiree's family. The man warns Armand that should Desiree proved to be black; Armand could not blame anyone but himself since before the marriage he did not care about the matter. Armand himself had said it does not matter since he can give her one of the oldest and proudest name in Louisiana, but once Armand notices that the child was not white and he accuses Desiree of being black, he wants to get rid of them because they have humiliated his family's name. "Chopin portrays Armand as a relentless man who is blinded by the dominant patriarchal convention. He bears a proud name and has a respectable position in society which he cannot lose to a son of a black woman" (Sulha, 2014: p.277). The last line is a strong irony as Armand's mother is black; so most likely his father already mortified the family in its expectations when he married her, giving her the name that is the oldest and the proudest in the district!

When Madame Valmonde comes to visit Desiree and the baby after four weeks she says, "This is not the baby!" she exclaimed, in startled tones, then she lifted it and walked with it over to the window that was lightest. She scanned the baby narrowly"(ibid, 241). Madame Valmonde notices that the baby is not white that is why she scans the baby ironically, instead of telling Desiree she asks what Armand thinks of the baby. Desiree says, "Oh, Armand is the proudest father in the parish, I believe, chiefly because it is a boy, to bear his name; though he says not, - that he would have loved a girl as well. But I know it isn't true I know he says that to please me. And mamma, she added, drawing Madame Valmonde's head down to her, and speaking in a whisper, "he hasn't punished one of them-not one of them-since baby is born" (ibid). Here Desiree's speech is ironic, it is situational irony as it will turn out to be the opposite since this is not at all what Armand desired: he now gets someone who can hold the oldest and proudest 
name in Louisiana, but it also puts the family name in jeopardy. It is ironic in the sense that Armand has not penalized any of his black slaves since the baby is born, not knowing that the baby has African blood in him. After Armand realizes that the baby is not white; there is a sudden change in his manner. He rejects his wife and the baby and treats his black slaves with great harshness and cruelty once again. The narrator describes his manner saying that there is

a strange, an awful change in her husband's manner, which she dared not ask him to explain. When he spoke to her, it was with averted eyes, from which the old lovelight seemed to have gone out. He absented himself from home, and when there, avoided her presence and that of her child, without excuse. And the very spirit of Satan seemed suddenly to take hold of him in his dealings with the slaves. Desiree was miserable enough to die (ibid).

The scene is ironic not only because of the way Armand starts to treat Desiree and make her miserable enough to die but it actually does cause her death. When Desiree herself notices that something is wrong with the baby she asks Armand what it means and he responds with, "It means," he answers lightly, "that the child is not white; it means that you are not white." Desiree answers that "It is a lie; it is not true, I am white! Look at my hair, it is brown; and my eyes are gray, Armand, you know they are gray. And my skin is fair," seizing his wrist. "Look at my hand; whiter than yours, Armand". Here, Desiree's speech is a verbal irony as well as Armand's response, "As white as La Blanche's" (ibid, p243) as La Blanche is one of his black slaves. If we take the meaning of the word Blanche means she is really white, but that is not Armand's meaning. Actually he is underestimating Desiree. It is ironic that Armand blames Desiree for having black ancestry when it turns out that he is the one who is half black. The writer makes the reader aware, through the course of the story, of the fact that Desiree is white. Her palms are whiter than his because he is not white, he is half black.

After Armand's accusation, Desiree writes to her adoptive mother saying, "My mother, they tell me I am not white. Armand has told me I am not white. For God's sake tell them it is not true. You must know it is not true. I shall die. I must die. I cannot be so unhappy and live" (ibid). The irony of these lines is that she does not like to live since she is accused of having black ancestry in her blood. Desiree knows to what extent Armand hates the black slaves, she is quite aware from the way her husband treats them: knowing that she is a part of them cannot make her happy so accordingly the only thing that allows her to regain her dignity is to commit suicide and to kill her baby. She cannot have a slave-like life. Moreover, another irony in this story is the way in which Chopin describes her heroine when she leaves her home, on her way to killing herself and her baby. The irony behind her description is that Desiree is described as an innocent and pure woman and she is compared to an angel wearing a white garment. How could she be an angel given she wishes to kill both herself and her baby simply on the basis that she has been told that she is not white? One more important point that is again ironic is that Desiree is always associated with whiteness, whereas Armand is consistently associated with darkness. Desiree's last decision to leave Armand is more determined and concentrated than any other situation in the story: ironically, she shows great strength and determination not to look back and beg her husband to accept her but instead to go on and kill herself and her baby. It is a point of action and self-assertion rejecting all types of discrimination: gender, racial, and class as "She disappeared among the reeds and willows that grew thick along the banks of the deep, sluggish bayou; and she did not come back again" (ibid, p.245). The most significant ironic point, which is a great surprise for the reader, is that at the end of the story, when a few weeks later, Armand burns all of the belongings of Desiree and his son: as he is burning the last of their things, Armand begins to go through letters; when Armand started burning the letters, he found a letter from his mother to his father that says, "She was thanking God for the blessing of her husband's love:-"But, above all," she wrote, "night and day, I thank the good God for having so arranged our lives that our dear Armand will never know that his mother, who adores him, belongs to the race that is cursed with the brand of slavery" (ibid, p.245). So here is the greatest irony in the story, it becomes apparent that Armand is the one who, all along, has an African American ancestor, not his wife. All the ironies of the story are related to these lines. Armand has to be blamed for everything, not Desiree. His sense of superiority makes him lose his wife and his boy baby and lose his self-esteem. Overall, his racialist attitude ruins his life as it is stated in the story that he has the oldest and the proudest family name in Louisiana.

Again the story is highly ironic, most of the situations that are created and tackled by Chopin are deeply ironic. Ironies are used to create an atmosphere of suspense; to give the reader an idea about the theme of the story and also to lead the reader to the real facts in a very engaging and indirect way. In Desiree's Baby, through the use of irony, Chopin highlights the theme of 'miscegenation' in southern Creole society. She rejects all kinds of discriminations relating to the place of women in marriage in the mid- nineteenth American society.

\section{CONCLUSION}

One of the characteristic features of Kate Chopin's writing is the use of irony. Her irony is neither humorous nor funny but most of the time tragic. Her tragic irony is deeply related to her disappointments with the 
contemporary concepts of her age. Chopin utilizes irony in her stories intentionally. She uses irony to change a dull and boring matter into an intriguing one simply by making something happen most probably that is unexpected to happen, thus to shock the readers by adding turns and twists to the stories, to create an atmosphere of suspense. Chopin employs irony to convey her message and to lead the readers to the main theme of the story. The stories place great value on woman's autonomy, criticizing the discriminatory society of her lifetime in America, and support the author's feminist ideas. She uses irony to turn or twist the fate of her women characters, tired of a domestic role, in search of personal freedom and a life full of personal success and self-recognition. Her ironic stories are akin to a revolution against the conventional patriarchs of American society in the mid-nineteenth century.

\section{REFERENCES}

Abrahams, M.H. and Harpham, G. G. (2009). A glossary of literary terms. Canada: Wadsworth Cengage Learning.

Boriçi, F. (2013) 'The Conflict between the Spiritual and the Sensual Dimension in Kate Chopin's Short Stories', Mediterranean Journal of Social Sciences. Walter de Gruyter GmbH. doi: 10.5901/mjss.2013.v4n9p314.

Boriçi, F. (2014) 'Kate Chopin: Beyond Local Color to Feminism', Journal of Educational and Social Research. Walter de Gruyter GmbH. doi: 10.5901/jesr.2014.v4n2p310.

Boriçi, F. (2014) 'Emancipation: A Constant Theme in Kate Chopin's Short Stories', Journal of Educational and Social Research. Walter de Gruyter GmbH. doi: 10.5901/jesr.2014.v4n4p248.

Chopin, Kate. (1969), The Complete Works of Kate Chopin. Baton Rouge: Louisiana State University Press. Muse.jhu.edu/book/33760.

Clark, P. (July 27, 2019). The Kate Chopin International Society. Retrieved from https:/ / www.katechopin.org/biography/

Hicks, Victoria. (2009), Patriarchal Representation and Domestic Liberation: The Home in Kate Chopin's Short Fiction, The University of North Carolina at Asheville.

Kate Chopin (n.d.). Retrieved April 2, 2019, from American Literature website, https://americanliterature.com/author/katechopin/bio-books-stories

Li, Xiang, (2008). Irony Illustrated: A Cross-Cultural Exploration of Situational Irony in China and the United States. Sino-platonic papers, 184. University of Pennsylvania, Philadelphia, PA 191046305 USA. Retrieved from http://sinoplatonic.org/complete/spp184_chinese_irony.pdf

Peel, Ellen (1990). Semiotic Subversion in "Désirée's Baby". American Literature Vol.62. Durham, NC: Duke University Press. 223-237.

Şulha, P. (2014) 'Chopin's Désirée's Baby and its Translation into Turkish: A Stylistic Approach', Procedia - Social and Behavioral Sciences. Elsevier BV, 158, pp. 273-278. doi: 10.1016/j.sbspro.2014.12.087

Taş, Mehmet Recep. "Kate Chopin's The Awakening in the Light of Freud's Structural Model of the Psyche." Uluslararasi Sosyal Araştırmalar Dergisi/Journal of International Social Research 4.19 (2011): 413-418.
Wolff, Cynthia Griffin (1978). Kate Chopin and the Fiction of Limits. The Southern Literary Journal Vol.10. Chapel Hill: University of North Carolina $\quad$ Press. 123-133. http://www.jstor.org/stable/20077591

Wyatt-Brown, Bertram (2002). Walter Lynwood Fleming Lectures in Southern History: Hearts of Darkness: Wellsprings of a Southern Literary Tradition. Baton Rouge, LA: Louisiana State University Press.

Wyatt, Neal (1995). Biography of Kate Chopin. Retrieved from http://www.vcu.edu/ engweb/webtexts/hour/katebio.html 